\title{
The Effect of Foreign Direct Investment on the Hospitality Industry in Liberia: A Case Study on the Chinese Investment
}

\author{
Loretha Adjuah Blamoh ${ }^{1}$, Yang Jingyi ${ }^{1}$, Wen Meixue ${ }^{1} \&$ Gao Weiijie ${ }^{1}$ \\ ${ }^{1}$ School of Tourism Management, Zhengzhou University, Zhengzhou City, Henan Province, China \\ Correspondence: Loretha Adjuah Blamoh, School of Tourism Management, Zhengzhou University, Zhengzhou \\ City, Henan Province, People's Republic of China. E-mail: drdugau2019@gmail.com
}

Received: November 17, 2020

Accepted: December 12, 2020 Online Published: December 25, 2020

doi:10.5539/ijef.v13n1p111

URL: https://doi.org/10.5539/ijef.v13n1p111

\begin{abstract}
Foreign Direct Investment is said to have a positive impact on the development of the hospitality industry in developing countries. It helps create employment opportunities and positively impact local economies. The present study research published articles, desk reviews, scientific databases among others to report the results. Current findings showed that the success of the hospitality industry in developing countries depends on the levels of Foreign Direct Investment. Although many developing countries have natural features such as beaches, rivers, and other natural resources, local capital to invest in those resources is unavailable. Tourism shows particular promise for developing countries. The tourism industry is one of the largest and fastest-growing sectors in the global economy and a key driver of socio-economic development, as it is labor-intensive and stimulates SME growth and investment. It has been used in other countries as an economic driver for growth which can widely support poverty reduction.
\end{abstract}

Keywords: Foreign Direct Investment, tourism, hospitality industry, economic growth, and poverty reduction

\section{Introduction}

Tourism is an important poverty reduction tool that can create jobs that attract youth employments, create jobs for women, boost the economy, encourage investment, decentralize development activities, promote the wealth, beauty, rich culture, and heritage of the Republic of Liberia (Cohen \& Kennedy, 2018). Tourism is an industry of industries and Liberia stands to benefit greatly from a culturally, vibrant, inclusive sustainable tourism industry. Tourism has emerged as a significant export for many developing countries. There exists a consensus that tourism has not only increased the foreign exchange income but has improved employment and stimulated growth, thus triggering the growth in all sectors of the economy (Cohen \& Kennedy, 2018). There exists generally a belief that tourism has a significant role to play in developing countries to achieve growth and sustainability. Foreign Direct Investment (FDI) plays a significant role in mitigating the effects that are caused by the development gap between developing and developed countries (Dwyer, 2015). China has emerged recently as a significant foreign investor in developing countries and especially in African countries (Lafargue, 2015). Liberia has benefited from China's direct foreign investment in the tourism sector, health, and infrastructure (Dwyer, 2015). Tourism as we see more often has become one of the world's largest industries and one of its fastest-growing economic sectors. We have seen many countries in and out of Africa where tourism is seen as the main mechanism for development, as it stimulates new economic activities (Baum, 2016). Liberia is rich in culture and has potential for amazing eco, adventure, wildlife, coastal and marine tourism, however, there are some challenges Liberia must overcome from the negative image of the COVID-19 crisis, which Liberia has to overcome as a nation, to infrastructure challenges in accessing certain parts of the country, data collection, complete inventory, and human capacity challenges (Sirleaf \& Nagba, 2015). Liberia is a country in transition, fortified by recent accession to the World Trade Organization (WTO), a decade of economic growth, a private sector hungry for success, and a public sector willing to facilitate this growth (Baokai, 2017). The country made impressive strides in the period between the end of the civil war and the recent Ebola outbreak. With the epidemic under control and a Government determined to steer the brand of the country away from images of conflict and disease, the focus has converged on one sector (Nyei, 2016). Liberia is known for its vast wildlife, beautiful lakes, beaches, waterfalls, rain forests, and species such as marlins, swordfishes, whales, and dolphins, which offer significant opportunities for touristic activities. Liberia's tourism sector is characterized by an 
unbroken sand stripe, unexplored beaches, and waterfalls that need serious investment (Nyei \& Kamara, 2016). Liberia tourism can be subdivided into four categories: wildlife sites and attractions, eco-tourism sites and attractions, surf-based tourism, and culture and heritage attractions and sites.

\section{Materials and Methods}

Several studies have been conducted on Foreign Direct Investment in developing countries of Africa. However, only a few of these studies have presented explanations about Foreign Direct Investment in the hospitality industries, and none of them have reported about Foreign Direct Investment (Chinese investment) across the hospitality industries of Liberia. Therefore, this study collected, documented, and compared detailed results about Foreign Direct Investment in the hospitality industries of Liberia and its effects. The literature search was conducted by using the following search term: "Foreign Direct Investment across the hospitality industries of Liberia". As there are few studies about Foreign Direct Investment across the hospitality industries of Liberia, the authors included available information found in scientific databases, a desk review of articles, reading available books and reports, and from searching scholarly journals for research articles about Foreign Direct Investment across the hospitality industries. In addition, the Literature search assesses the relationships between Foreign Direct Investment and the hospitality industry. In this literature review, the authors respected the original authors' definitions, descriptions, methodology, and reported results. During the literature review search, various information and results were obtained about Foreign Direct Investment and the hospitality industry, but the review's objectives were prioritized. The authors are aware that there might be doubts about the analytical results presented in some of the figures or tables. It should be understood, however, that each research team uses a specific analytical tool and that it is practically impossible to streamline the results in such a way that they could be compared using the same standards. The readers are referred to the original articles for further details.

\section{Results}

\subsection{Expansion of Chinese FDI's in Liberia}

The Chinese government has, in the recent past invested in Liberia. Beijing's win-win diplomacy and its approaches to socio-economic and infrastructural development have encouraged trade and investment between China and Liberia. Such partnerships have been influenced by the Forum on China-Africa Corporation (FOCAC) that has emerged as a platform for China and Liberia to engage in multilateral trade discussions based on win-win standing for both countries (Shinn \& Eisenman, 2012). Liberia and China have had a strong connection and ties ever since Liberia became part of FOCAC. Through FOCAC, Liberia and China have had excellent economic relationship and cooperation in the last couple of years. Liberia has taken advantage of its membership of FOCAC to increase economic development, improve its infrastructure, and increase human resource development (Risso, 2018). FOCAC was formed in 2000 when Liberia was in the heat of the civil war, since joining it, FOCAC has played an important role in the development of all sectors (Shinn \& Eisenman, 2012). The recent trends on the relationship between China and Liberia identify that the fact that relations are moving in the right direction whose vision is to achieve a shared future and cooperation that is based on the fight and struggle against imperialism in both countries and the achievement of national independence. FDIs have had a lot of impact on the GDP of the country. The table below shows the relationship between FDI and growth of GDP using the panel data for the last 15 years.

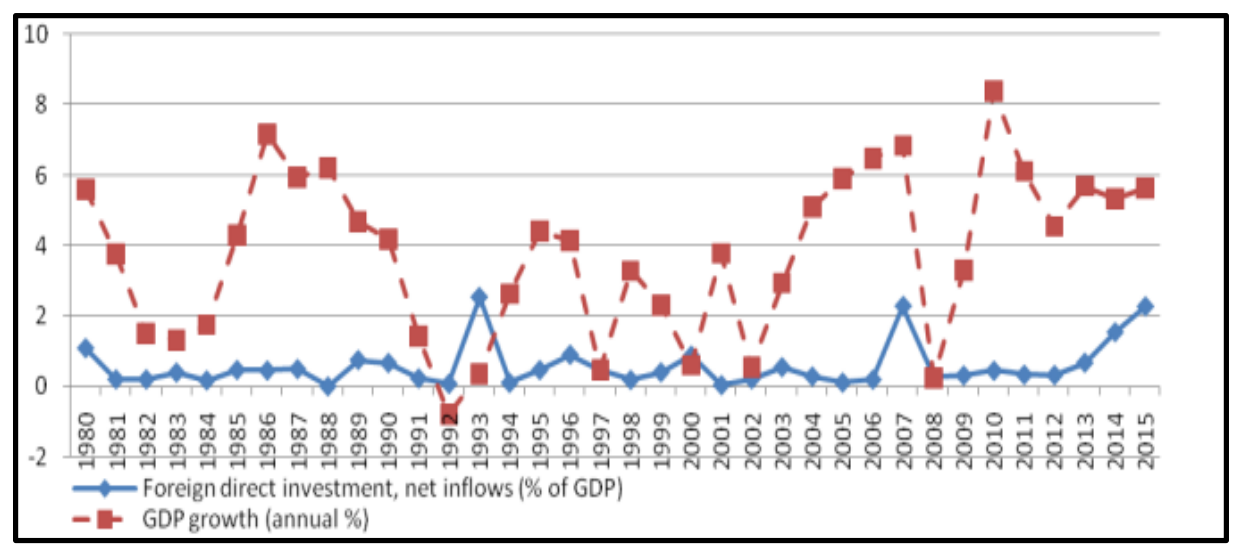

Figure 1. Relationship between Chinese FDI and GDP growth

Source: World Bank. 
Chinese FDI in the country has been focused on bilateral projects such as the building of the national sports stadium, the improvement of the health care facilities, and the improvement of the tourism sector (Risso, 2018). The greatest challenge to Liberia at the moment to be able to create favorable conditions for the flow of direct investments from China. While the tourism sector has benefited immensely from the China-Liberia relations, other sectors of the economy such as the infrastructure with the building of the Chinese Building University of Liberia, installation of traffic lights in Monrovia, rebuilding of the Samuel K Doe sports complex, and the rehabilitation of the Jackson Doe Medical Centre (Busse, Erdogan, \& Mühlen, 2016).

Table 1. Demographic data of respondents (A respondents distribution by Gender)

\begin{tabular}{ccc}
\hline Gender & Frequency & Percentage \\
\hline Male & 40 & $80 \%$ \\
Female & 10 & $20 \%$ \\
Total & $\mathbf{5 0}$ & $\mathbf{1 0 0 \%}$ \\
\hline
\end{tabular}

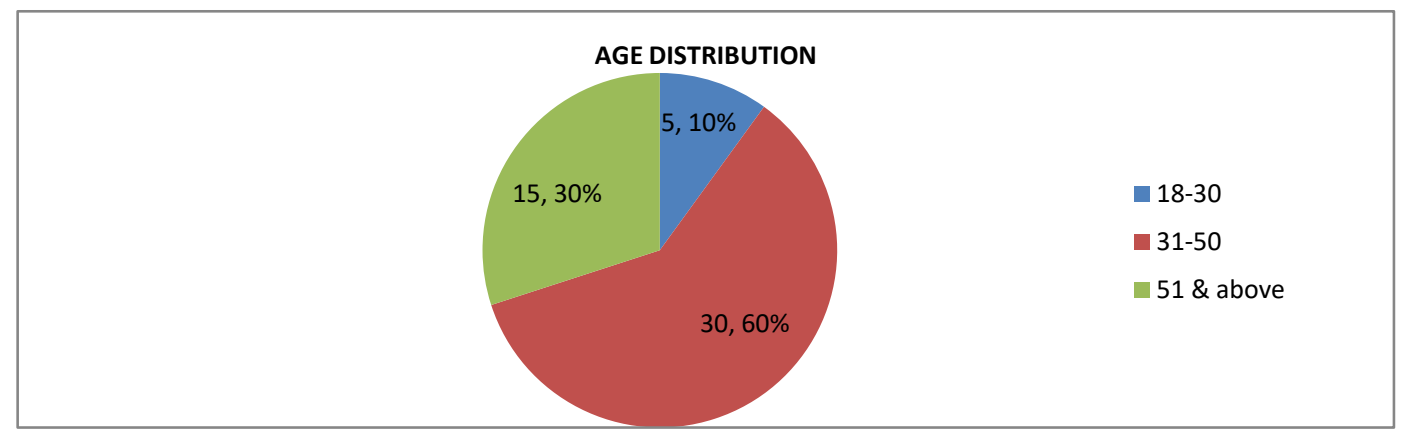

Figure 2. Age distribution

Table 2 shows the age distribution of respondents in this category. Five respondents that constitute $10 \%$ of the sampled size are between the ages of 18-30, while 30 respondents accounting for $60 \%$ are between the ages of $31-50$, and fifteen respondents accounting for $30 \%$ were people between the ages of 51 and above.

Table 2. Frequency distribution showing the education of respondents

\begin{tabular}{ccc}
\hline Education Status & Frequency & Percentage \\
\hline High school diploma & 1 & $2 \%$ \\
College student & 4 & $8 \%$ \\
College graduate & 10 & $20 \%$ \\
Master degree student & 15 & $30 \%$ \\
Holder of Master's degree & 18 & $36 \%$ \\
Total & $\mathbf{5 0}$ & $\mathbf{1 0 0 \%}$ \\
\hline
\end{tabular}

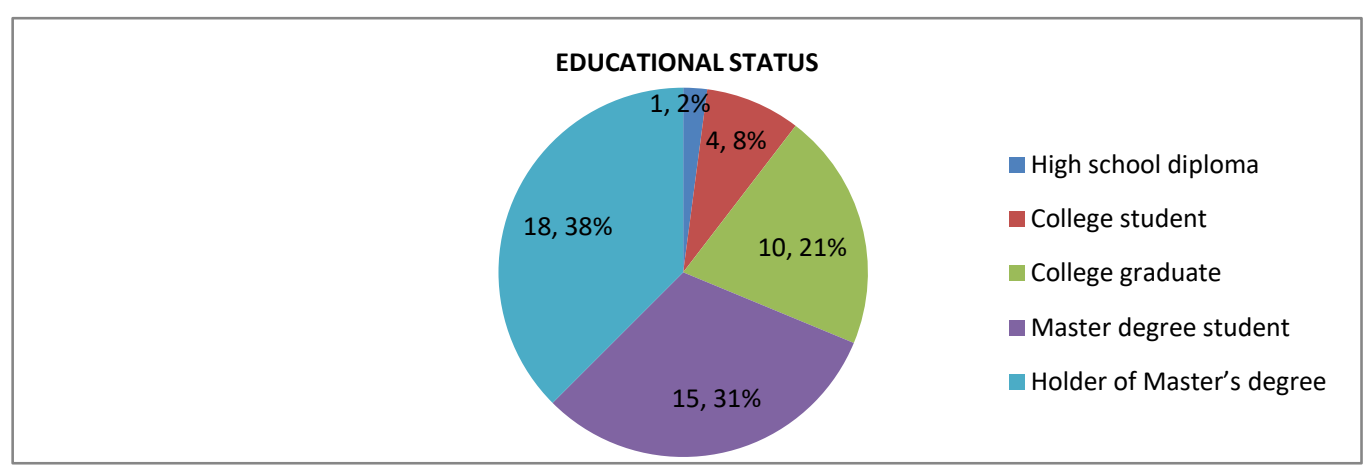

Figure 3. Educational status 
This table indicates that $2 \%$ of the respondents are high school graduate, $8 \%$ also account for college students, $20 \%$ college graduate, $30 \%$ are master degree students, $36 \%$ of the respondents are the holder of master's degree and $4 \%$ of the respondents are at another level.

Table 3. Nationality of respondents

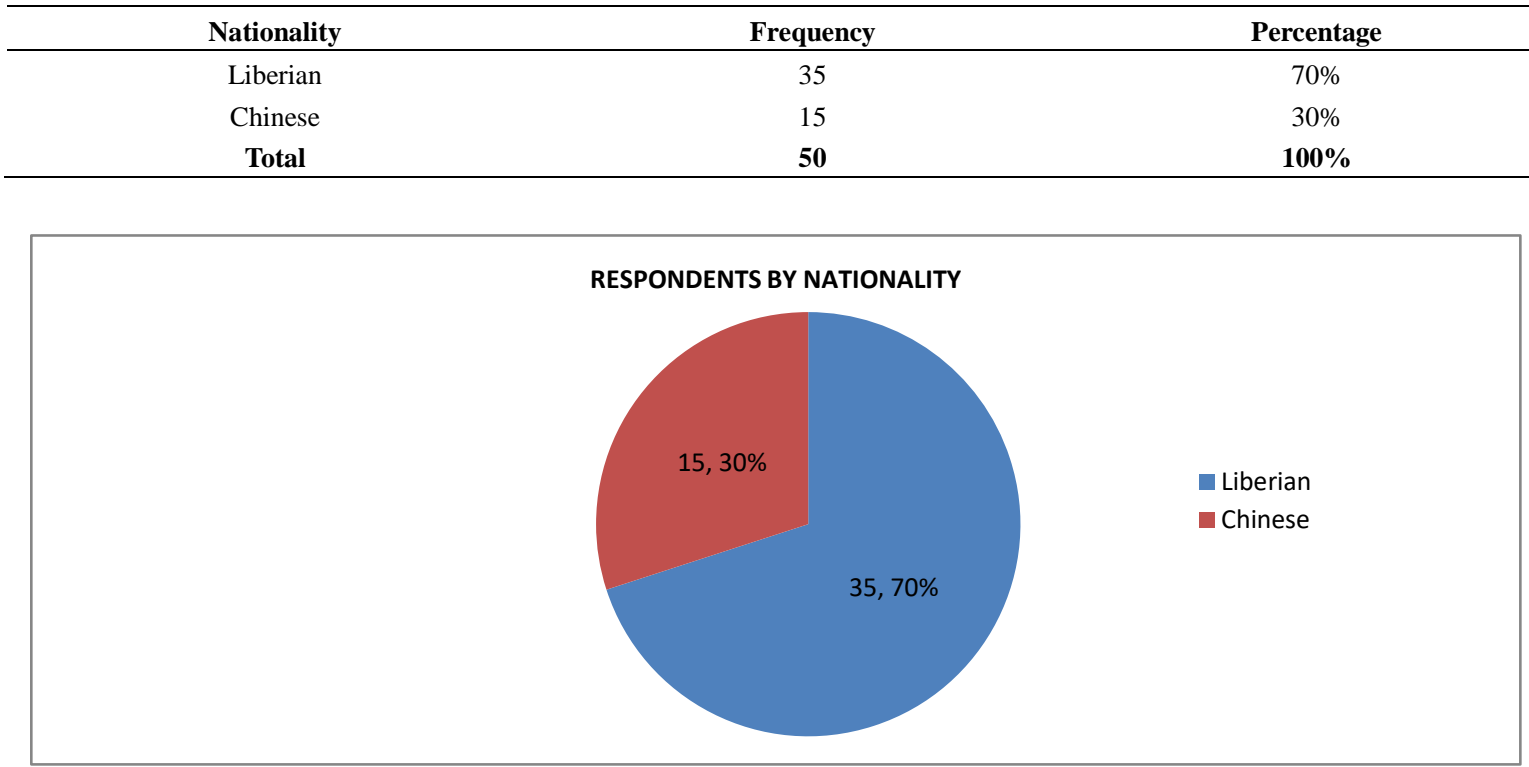

Figure 4. Respondents by nationality

Table 3 indicates $70 \%$ of the respondents account for Liberian citizens who are directly involved with the business in the tourism sector and $30 \%$ of the research respondents are Chinese.

Table 4. Impact of Chinese FDI in Liberia on the growth of the tourism

\begin{tabular}{llcc}
\hline Question & \multicolumn{1}{c}{ Responses } & Respondents & Percentage \\
\hline What is the impact of Chinese FDI in & Chinese FDI helps in accelerating the rate of economic & 10 & $20 \%$ \\
Liberia on the growth of tourism? & growth in the tourism sector by providing capital & & $30 \%$ \\
$\begin{array}{l}\text { What is the impact of Chinese FDI in } \\
\text { Liberia on the growth of tourism? }\end{array}$ & $\begin{array}{l}\text { It helps eradicate poverty, promote the beauty and rich } \\
\text { cultural heritage of Liberia }\end{array}$ & 15 & \\
$\begin{array}{l}\text { What is the impact of Chinese FDI in } \\
\text { Liberia on the growth of tourism? }\end{array}$ & FDI provides increased employment in the tourism sector & 25 & $50 \%$ \\
Total & and helps boost infrastructure development in Liberia. & $\mathbf{5 0}$ & $\mathbf{1 0 0 \%}$ \\
\hline
\end{tabular}

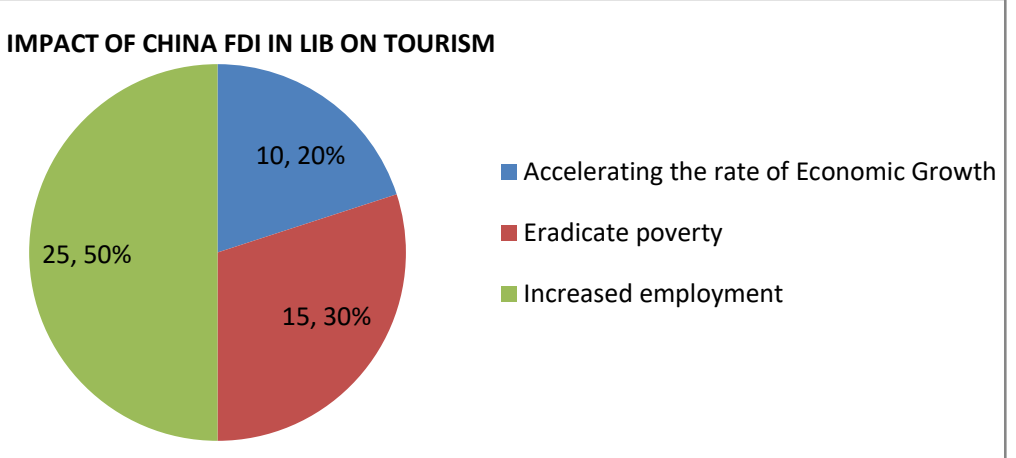

Figure 5. Impact of China FDI on tourism in Liberia

In table 4, 10 respondents accounting for $20 \%$ of the sampled population admitted that the role of FDI and its impact on economic growth is that it helps in accelerating the rate of economic growth by providing capital. On 
the other hand, 15 respondents constituting $30 \%$ of the sampled population said FDI provides an inflow of foreign exchange resources and removes the constraints on the balance of payment. Lastly, 25 respondents accounting for $50 \%$ of the sampled population said FDI provides increased employment.

Table 5. Perceptions of the Liberians on the state of tourism sector since the entry of Chinese FDI

\begin{tabular}{llcc}
\hline \multicolumn{1}{c}{ Questions } & \multicolumn{1}{c}{ Responses } & Respondents & Percentage \\
\hline $\begin{array}{l}\text { What are the perceptions of Liberians on the State } \\
\text { of Tourism Sector since the Entry of the Chinese? }\end{array}$ & $\begin{array}{l}\text { Creates employment opportunities for local } \\
\text { members in my community }\end{array}$ & 10 & $20 \%$ \\
$\begin{array}{l}\text { What are the perceptions of Liberians on the State } \\
\text { of Tourism Sector since the Entry of the Chinese? }\end{array}$ & $\begin{array}{l}\text { Tourism in Liberia contributes to the personal } \\
\text { income of residents in my community }\end{array}$ & 8 & $16 \%$ \\
$\begin{array}{l}\text { What are the perceptions of Liberians on the State } \\
\text { of Tourism Sector since the Entry of the Chinese? }\end{array}$ & $\begin{array}{l}\text { Tourism brings in foreign exchange earnings } \\
\text { and regional development in my community }\end{array}$ & 15 & $30 \%$ \\
$\begin{array}{l}\text { What are the perceptions of Liberians on the State } \\
\text { of Tourism Sector since the Entry of the Chinese? }\end{array}$ & $\begin{array}{l}\text { Tourism increases the cost of living in my } \\
\text { commity }\end{array}$ & 12 & $24 \%$ \\
$\begin{array}{l}\text { What are the perceptions of Liberians on the State } \\
\text { of Tourism Sector since the Entry of the Chinese? }\end{array}$ & $\begin{array}{l}\text { Real estate prices in my community have } \\
\text { undertaken in my community }\end{array}$ & 5 & $10 \%$ \\
Total & & $\mathbf{5 0 \%}$ & $\mathbf{1 0 0 \%}$ \\
\hline
\end{tabular}

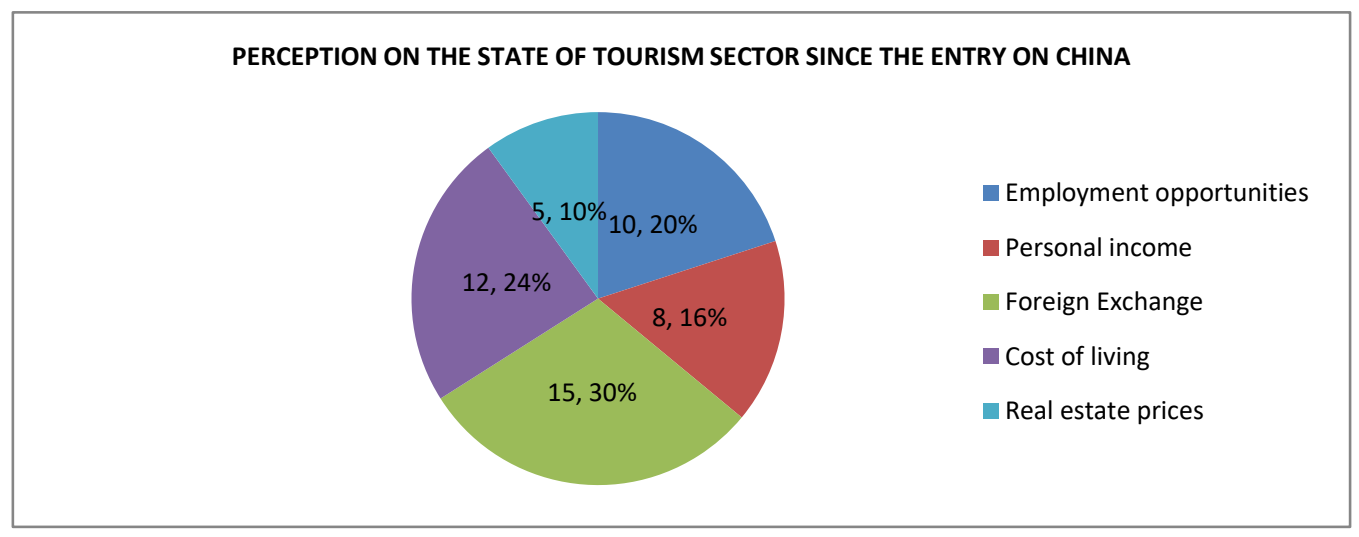

Figure 6. Perceptions of Liberians on the state of tourism

Table 5 shows the perceptions of Liberians on the state of the tourism sector since the entry of Chinese FDI. In this table, 10 respondents accounting for $20 \%$ hold the perception that the tourism sector creates employment opportunities for local members in my community, while 8 respondents accounting for $16 \%$ hold the view that tourism in Liberia contributes to the personal income of residents in my community, 15 respondents that account for $30 \%$ of the sampled population hold the perception that tourism brings in foreign exchange earnings and regional development in my community, while on the other hand 12 respondents accounting for $24 \%$ perceived that tourism increases the cost of living in my community and 5 respondents accounting for $10 \%$ hold the strong perception that real estate prices in their community have increased due to the amount of tourism undertaken in their community.

Table 6. Causes of the fluctuating growth rates of FDI/GDP?

\begin{tabular}{cccc}
\hline Question & Responses & Respondents & Percentage \\
\hline What are the causes of the fluctuating growth rates of FDI/GDP? & A decline in national income or wage & 30 & $60 \%$ \\
What are the causes of the fluctuating growth rates of FDI/GDP? & Fragile rule of law & 5 & $10 \%$ \\
What are the causes of the fluctuating growth rates of FDI/GDP? & Contraction of the economy & 12 & $24 \%$ \\
What are the causes of the fluctuating growth rates of FDI/GDP? & Low physical capital or infrastructure & 3 & $6 \%$ \\
& and low human capital & $\mathbf{5 0}$ & $\mathbf{1 0 0 \%}$ \\
\hline
\end{tabular}




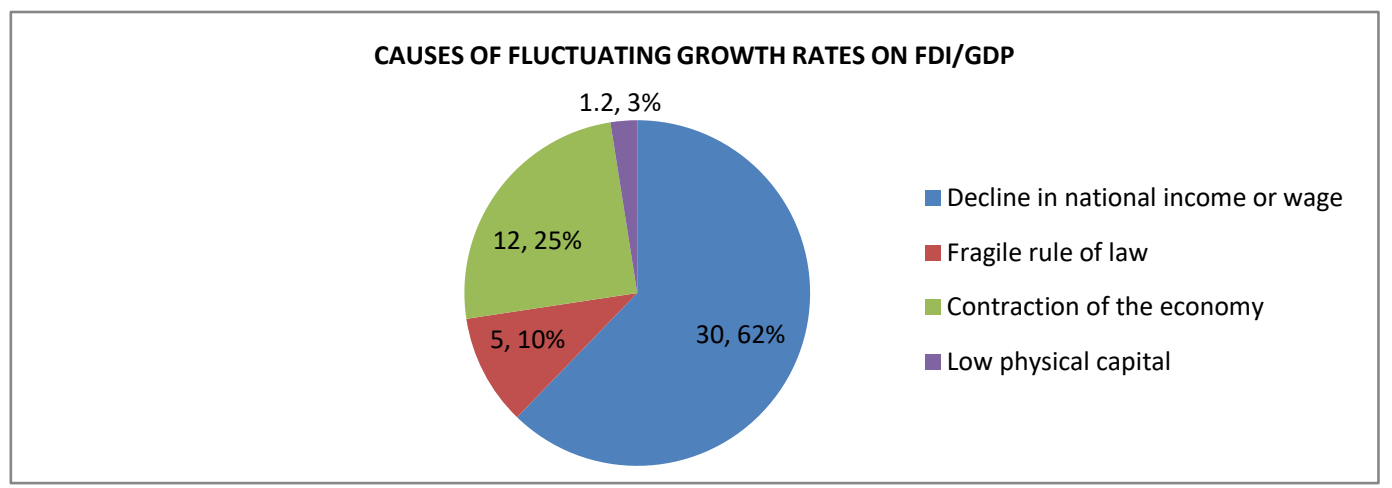

Figure 7. Causes of fluctuating growth rates on FDI/GDP

Table 7 shows the causes of the fluctuating growth rate of FDI/GDP. In the table, 30 respondents accounting for $60 \%$ of the sampled population said a decline in national income or wages are the causes of the fluctuating growth rate of FDI/GDP, while 5 respondents accounting for $10 \%$ of the sampled population said fragile rule of law, 12 respondents accounting for $24 \%$ said the contraction in the economy and lastly, 3 respondents accounting for $6 \%$ said low physical capital or infrastructure and low human capital are the causes of the fluctuating growth rate of FDI/GDP.

Table 7. A solution to solve the problem

\begin{tabular}{clcc}
\hline Question & \multicolumn{1}{c}{ Responses } & Respondents & Percentage \\
\hline What solution can be recommended to solve the problem? & $\begin{array}{l}\text { Capacity building for people working in the } \\
\text { tourism industry }\end{array}$ & 15 \\
What solution can be recommended to solve the problem? & $\begin{array}{l}\text { Undertake joint marketing including packaging } \\
\text { and promotion of cross-border attractions }\end{array}$ & 5 & $10 \%$ \\
What solution can be recommended to solve the problem? & Building roads and access points & 30 & $60 \%$ \\
Total & & $\mathbf{5 0}$ & $\mathbf{1 0 0 \%}$ \\
\hline
\end{tabular}

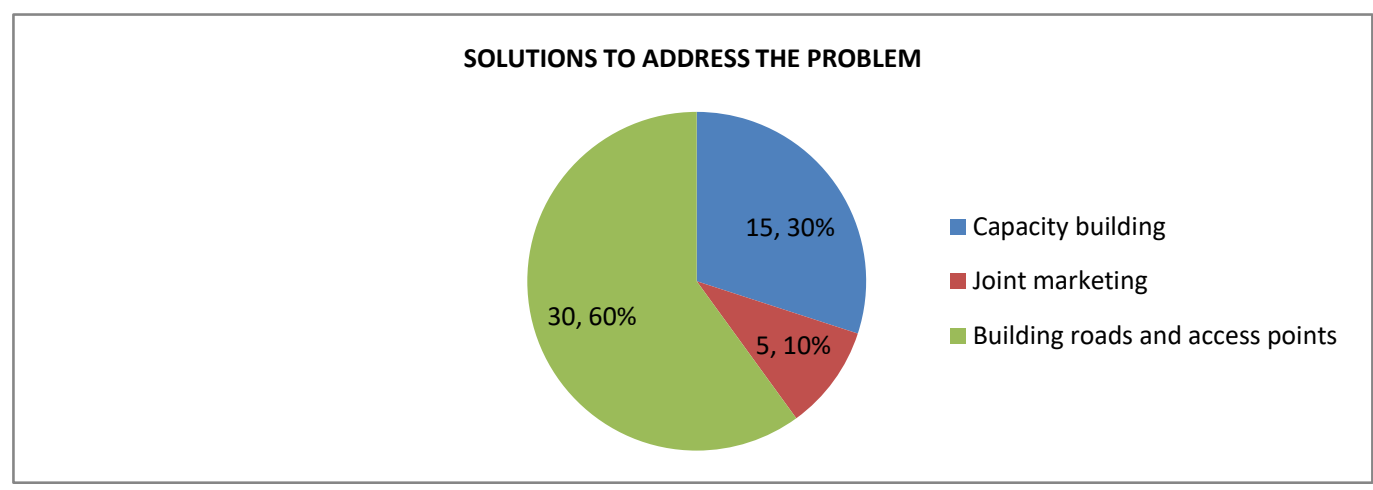

Figure 8. Solutions to problem

Table 7 shows the solutions to address the challenges in the tourism sector in Liberia. In the above table, 15 respondents accounting for 30\% recommended capacity building for people working in the tourism industry, while 5 respondents accounting for $10 \%$ suggested that the government should undertake joint marketing including packaging and promotion of cross-border attractions and 30 respondents that constitute $60 \%$ recommended building roads and access points to address some of the constraints in the tourism sector.

\section{Discussion}

\subsection{The Liberian Tourism Value Chain}

Liberia possesses excellent conditions for coastal and maritime tourism. Among the country's current tourism offerings, there are surfing and surfing-related activities - particularly in Robertsport - deep sea fishing, Buchanan, etc. Liberia's tropical coast, beaches with warm ocean temperatures year-round, and rich marine 
resources offer great potential for tourism (Kamara, 2016). Certain activities such as surfing and fishing in Liberia are gaining increasing international attention as tourist attractions. Liberia enjoys a rich natural capital with high touristic potential. Liberia's natural attractions include two natural forest reserves, wetlands and mangroves, and biological and landscape diversity (Abdillah, 2015).

\subsubsection{Ecotourism}

One of the main natural sites with ecotourism potential in Liberia is Kpatawee Waterfalls, managed by a local community. The waterfalls are about three hours away from Monrovia by car and the road is paved for the largest part of the route. Being surrounded by a dense forest, Kpatawee Waterfalls possess an attractive combination of natural beauty and local friendliness. Two cascades exist, the smaller being the closest to the road, and the bigger one reachable by roughly an hour of trekking (Janianton, 2015). Liberian nationals already enjoy events and activities in this location despite the current lack of basic amenities services, e.g. food and beverages. Ecotourism activities would create a great impact on the socio-economic development of the local community.

Other Liberian natural sites with potential for ecotourism are the several cultural villages across the country (e.g. Behsao), Edina, and Libassa Ecolodge. Ecotourism practices are already being implemented in the latter. The Atlantic coast of Liberia also features an abundance of maritime resources. The aquatic fauna of Liberia is diverse and is the basis of important economic activity for the country. These resources can also have economic potential for tourism. Sailing and sport fishing activities, whether for beginners or experts (extreme fishing) can be carried out within Liberia's Exclusive Economic Zone (186,322.2 km2). Further, Liberia would be highly attractive for fishing aficionados due to the abundance of species such as marlin, tuna, and swordfish, considered big game fish - i.e. large fish renowned for their sporting qualities - which can be found only an hour away from the coast Augustine, 2017).

\subsubsection{Current Performance of the Liberian Tourism Sector}

Tourism is a labor-intensive sector which can potentially be a significant contributor to the Liberian economy. In 2010, the Liberian tourism industry directly employed 195,000 people. Moreover, $74.7 \%$ of tourism-related employment is estimated to benefit women, indicating that sectorial growth would have strong implications for gender issues (Cohen, 2008).

Although there are insufficient data regarding the number and origin of international arrivals to the country, it is estimated that most foreign travelers are European and United States nationals. Three categories of tourists exist, based on the current core tourist offerings in the country (i.e. sports, nature, and historical). Business connections between domestic and international travel agents are almost non-existent and thus international visitors usually organize their travel through online booking platforms (Cooper \& Emory, 2006).

On the other hand, the relatively large expatriate community in Liberia working in United Nations entities and NGOs, along with Liberian nationals, constitutes another important market segment for the sector. International tourism receipts for Liberia were approximately $15.01 \%$ (US 232 million) of GDP in 2011. The contribution of international tourism in exports was $18.56 \%$ in the same year. There are no updated statistics regarding the contribution of the tourism sector to total employment. Nevertheless, the potential of tourism for employment creation in the country has been widely acknowledged. The limited availability of reliable statistics makes it difficult to describe with accuracy the size and dynamics of Liberia's tourism sector both in terms of volumes and value (A.C \& Hinkley, 2006). As mentioned previously, the Ebola virus caused high economic costs, particularly in the Liberian tourism sector. Hotels and restaurants were adversely affected by the reduction of commercial flights and occupancy from international visitors. Weekly flights diminished from 27 weekly in August to only six in September (2014). Likewise, some hotels reported $10 \%$ occupancy rates as a result of the crisis as a consequence, employment in the sector was negatively impacted as hotel workers were either laid off or had their working days reduced.30 Although there is no available information on the number of international visitors to Liberia, data from OAG (Air Travel Intelligence) estimates that total seat capacity was down by roughly 65\% in January 2015 compared with January 2014.31 (Djaali, 2008).

\subsubsection{Effect of Chinese FDI's and Growth of Liberia Tourism Sector}

The increased attention on China on African countries and its FDI on the tourism sector in Liberia has reignited the debate on the importance of foreign investment on the economic growth in the tourism sector and the eventual poverty eradication. Risso (2018) identifies that the foreign flow of capital brings long-lasting growth and flow of capital as most of the projects in the country are long term investments. One of the main effects on the economy is the competition that foreign companies tend to bring in the host country. Most companies in the tourism sector in the country have become more productive and have engaged in measures to counter the threat 
of the competitors. The higher productivity of these companies leads to immense growth in the economy of Liberia (Moumouni, 2018).

An increase in employment opportunism is another effect of foreign direct investment. As the nation becomes tourism sector becomes more productive, more sectors of the economy open up for growth which in the long increases employment opportunities. The technological know-how in the country also increases with the FDI. The FDIs allows for the transfer of technology that will be able to favor productivity and growth. The significance of the Chinese investment in the country is to improve technology in terms of how management is handled and practiced and has further increased the assured markets in the country. The value-added as a result of the increase in technology is the contribution that this has on the GDP and increasing the foreign exchange (Risso, 2018). Thus, the FDI is an immense tool that in the long run contributes to the increase in foreign exchange earnings, the job opportunities and eventually increases the earnings of the employees within Liberia.

Lastly, the development of infrastructure is one of the critical areas that the FDIs have impacted. Chinese has invested mainly in the tourism sector in Liberia with concerted efforts made on the development of the Samuel K Doe Sports Complex. It has been further arguing that countries that receive foreign direct investment have directed this to the development of infrastructure as compared to the provision of services (Risso, 2018). The entire infrastructure within the country that has in the past received little attention such as health and tourism can now enjoy the impact of the flow of capital from the more developed countries. Most studies in the field have argued out the fact that FDI is an important factor that increases the support of domestic companies and increases growth. Lanier et al. (2011) established that there exists a relationship between the improved standards of living in the Liberian economy and the FDIs. The researchers identify that the process of job creation and the industrial economic diversification is negatively impacted by various factors such as high energy cost that makes the production costs to be high and the low human capacity. This study identifies that FDI in Liberia plays an important role in the creation of jobs and has tamed the high rates of unemployment (Risso, 2018).

\subsubsection{The Growth of Tourism Sector in Liberia}

The tourism sector in Liberia is growing. The tourism sector in the county has competitive assets that remain untapped and underutilized. Over the last few years, there has been massive attention towards Liberia due to its rich culture and that ranges from beautiful sites, spectacular white-sand beaches, and the rainforests in the country (Dwyer, 2003). The country offers three main tourist features that include the cost and the marine, the natural features, and historical sites that extensive history and learning for tourists. The growth potential for the country's tourism sector is immense with natural wetlands, mangroves, and the biological and forest reserves that offer immense diversity to the viewers. However, despite the above growth, the provision of hospitality services still lacks in the country. There are investment opportunities for foreign investors to invest in Providence Island that is located in the heart of Monrovia and offers a great historical site of the emancipated slaves (Busse, Erdogan, \& Mühlen, 2016). Other areas of investments include the Robert sport, Lake Piso, and the Kpatawee Waterfall.

\subsubsection{Chinese Expansion in Africa}

The Chinese government has embarked on an expansionist policy and strategies across the world, and one of the regions that have received its attention is the African continent. Beijing's non-interference policy on social and political issues in African countries. President Xi Jinping in his book, the Governance of China TWO identifies for the last 66 years, the Chinese government has provided the African Continent with foreign aid worth RMB400 billion and will be able to increase the same over the next couple of years. Accordingly, Xin Jinping identifies that China has single handily contributed to $30 \%$ of the world's growth rate. The Forum on China-African Cooperation (FOCAC) has emerged as an important forum for the interaction between African Countries and China. China-Africa cooperation has been pushed to new heights after the Jonesburg summit of 2015 and the 2006 Beijing summit (Risso, 2018). The China-African fund is aimed to boost industrialization in the African countries by giving them loans of up to $\$ 10$ billion and further loans to support the African SMEs. While major Western powers have put into question the investment of China to African countries, China has been able to fill major investment gaps in the region that requires interventions. While this is the case, the impact of the Chinese investments in African is felt in the improvement of infrastructure and major sectors of the economy (Koku \& Farha, 2019).

\subsubsection{The Potential of Tourism for Developing Countries}

Today, tourism, broadly defined, is the world's largest industry. It links together a series of cross-cutting activities involving the provision of goods and services, from accommodation, transport, and entertainment to construction, agriculture, and fisheries (box I.2). The industry structure encompasses a wide diversity of players 
ranging from global transnational corporations (TNCs) to extremely small enterprises, hence potentially enabling several different scales and levels in the market to participate in the industry (Erhamwilda, Asep, \& Nurul, 2017).

Tourism's economic potential, as one of the world's fastest-growing industries, is already being harnessed in many developing countries and newer or emerging economies and regions. Not all of this tourism is international or North-South travel as is commonly assumed; regional and South-South tourism is also growing rapidly, opening up new opportunities for tourism service providers in developing countries (Ferdinand, 2006). Tourism is not a single activity; it is an agglomeration of many separate and related activities that include transport, accommodation, food and beverage services, cultural entertainment, conventions, and trade fairs, sports, and recreation. In addition, activities that are critical to the success of tourism include financial services, telecommunications, health services, and others, such as energy, water, security, and law and order. All of these far-reaching activities come together in the production and consumption of tourism (Ghazali, 2006).

Taking hotel accommodation as one possible core activity of tourism production and consumption, backward linkages established by hotels include those with suppliers of inputs that are needed for immediate consumption, such as meat and fish, dairy produce, and vegetables and beverages. Backward linkages also establish longer-term relationships such as with construction companies and manufacturers of equipment, linen, and uniforms. When these goods are produced locally they can have a powerful effect on improving the value-added in the host country, through consumption multipliers and multipliers associated with the value chain (Ghazali, 2012). There are also important forward linkages that include, in addition to hotels, the production of goods or services used by tourists, such as handicrafts, shopping, musical performances, spa or health treatments, and the employment of tour guides. Some commentators have argued that improvements in the depth and added value of a well-managed tourism strategy can also translate into economy-wide improvements in private sector investment and growth, via an improved business climate and market discipline (MICAT, 2006).

These services can be put together individually by each tourist, or they can be created as a package by tourism intermediaries that provide wholesale or retail services (such as tour operators or travel agents and local government agencies). The more that such local forward and backward linkages exist, the deeper can be a country's tourism economy, and the less it will rely upon imported inputs. If a country combines this depth with creativity and innovation, its economy can become more differentiated and more competitive vis-à-vis other destinations (Godfrey \& Clarke, 2000).

\subsubsection{FDI in Tourism}

Tourism is an activity where the capital, infrastructure, knowledge, and access to global marketing and distribution chains are critical. FDI is often considered one of the most effective engines for harnessing these elements. Hence most developing countries place a high priority - often the highest priority - on attracting such investment, some by experimenting with a variety of policies (Malhotra, \& Birks, 2007). However, the role of FDI in tourism is more nuanced than it is in some other sectors of the economy, and most countries approach it with a combination of hope and fear. It is valued because of what it can provide, but it is also feared for its impact upon economic and cultural independence, and its potential damage to the communities and the environment. In some countries, efforts to attract FDI in tourism sit uneasily alongside complaints that there is already too much FDI, or that foreign investors dominate the sector and do not pass the benefits of tourism on to the domestic economy (Monecke \& Leisch, 2012). A fine balance needs to be maintained for developing countries to capture the benefits of this growing economic activity at minimum or sustainable costs. However, the search for appropriate policies to help achieve this has been hindered by the fact that there is little recent literature on FDI and tourism in developing countries, particularly from an empirical perspective, or on a counterfactual that compares foreign and domestic investors. Its economic dynamics are not well understood, and there are important gaps in understanding its trends or its impact. Much has been usefully written about tourism in general, including tourism and development, pro-poor tourism, tourism in African countries, ecotourism, South-South tourism, and sustainable tourism. However, tourism sustainability is typically approached from an environmental and social perspective, and less so from an investment-oriented one Rakhmat (2001).

For example, there has been little if any mapping of the extent of FDI in tourism, let alone an estimation of its impact, even though many developing countries are giving top policy priority to attracting FDI in tourism.

Similarly, little is known about the linkages between FDI in tourism and the local economy, with a few exceptions (e.g. Lengerfeld \& Steward, 2004). And while a lot has been written about "leakages" to the balance of payments, there has been insufficient empirical evidence of the effect of FDI on a country's tourism balance 
sheet. Research is therefore needed to clarify how host countries can be more active partners in the value chain of international tourism in ways that enhance local skills, boost human capital stocks, and increase revenues. A commonly held view about FDI in tourism in developing countries is that there is too much of it, that it is dominant, and that TNCs do not disperse the benefits of tourism sufficiently widely through the host economy.

For example, a background note summarized the broad tone of the literature as follows: "many analysts argue that tourism, driven by foreign private sector interests, is not an activity suited to poverty elimination. They argue that economic benefits are not maximized because of the high level of foreign ownership, high leakages and the relative absence of local economic linkages" (UNCTAD 2001, p. 60). Similarly, there is the sense that tourism in developing countries is characterized by "high dependence on foreign capital and foreign management..." (ibid. p. 63; italics added by UNCTAD). Much of the critical literature was written in the 1970s and 1980s, although recent writers are still rather negative in their assessment of the role of TNCs.4 For example, Brohman (1996, pp. 54-55) cites the "problems of dependency, internal disarticulation and foreign exchange leakages usually associated with underdeveloped economies dominated by foreign-owned export enclaves", and argues that "foreign domination and external dependency often seriously reduce tourism's potential for generating broadly based growth, as well as the net financial advantages that the industry brings to developing countries." Irrespective of the veracity of such views, developing countries need to devote attention to strengthening the participation of the domestic economy in the tourism industry, and in part, this includes ensuring net positive linkages with TNCs.

\subsubsection{Some Perceptions of FDI in Tourism}

The notion of foreign domination is a common one, but foreign hotels can have visibility and a profile in a developing country that is larger than the size of their operations would suggest. Besides, the wide use of management contracts and franchising activities means that much of what appears to be foreign ownership is not. A hotel that has a foreign name is assumed to have foreign owners, although in many, possibly most, instances this is not the case. Such non-equity relations may still come under the umbrella of FDI, loosely defined, but in fact ownership and profits may be in domestic hands. In Kenya, for instance, it is frequently claimed that the bulk of the country's tourism infrastructure is owned by foreigners (IDS 2000), or that tourism revenues primarily benefit foreigners. This is evident from newspaper articles in 2005, one of which stated that "of Kenya's 290,000-plus tourist hotel bed(s), foreign hoteliers own 74.3 percent", or that "tour flights to Kenya are entirely in the hands of foreign airlines" and "foreign companies stationed in European and American capitals entirely control hotel bookings.

The UNCTAD team in Kenya frequently encountered such views when researching this project. Kenyan tourism enterprises argue that such information is incorrect and harms Kenya's chances of being a successful tourism economy. A representative of Kenya's Association of Tour Operators and the Kenya Tourism Federation said that the majority of licensed hotels and safari lodges on the coast, in Nairobi, in country towns, and the parks and reserves are owned by Kenyan companies, not foreigners. This is in line with the findings gathered through UNCTAD interviews and research associated with this project, which estimates that foreign ownership accounts for a share of around one third at the most, and generally much less. 6 In general there is a lack of information about the tourism industry structure in developing countries, including data on the true extent of foreign ownership.

The question of the distribution of revenues and profits between foreign tour operators and domestic hotels is important in all developing countries, and one of the policy recommendations made in this monograph (chapter IV) is that attention needs to be paid to strengthening the bargaining position of local hotels in the international tourism production chain. The objective would be to ensure that domestic enterprises gain from the global tourism boom not only in absolute terms but also in relative terms (Rosdakarya \& Riduwan, 2009). However, this is not to say that countries would be better off without foreign tour operators or hotel companies. For example, a Kenyan safari investor said, "The fact is that the overseas companies give a big boost to our tourism and we do receive payment in Kenya for all the services supplied here: tours, transport, park fees, accommodation, meals, and incidentals like laundry, regardless of where the client pays... even though the foreign tour operators maybe my competitors, I have to admit that (they) have an important part to play in developing our tourism industry" (Richards \& Wilson, 2006). The perceptions described above sometimes also reflect concerns about the involvement of historically disadvantaged peoples in the tourism value chain. This is understandable and, as an alternative to eschewing tourism activity, lessons might be taken from the Black Empowerment approach promoted in tourism in South Africa among other sectors of the economy (see for example http://www.thedti.gov.za/bee/beecodes.htm), or the use of other public initiatives to promote domestic entrepreneurship in poor and disadvantaged communities (Ritchie, 2003). 


\section{Findings and Conclusion}

The research study makes the following findings

1) The Chinese influence in Africa has greatly increased the positive bilateral relationship between many African countries and China

2) There has been great Chinese influence in Liberia in the last 10 years.

3) The immense Chinese presence in Liberia has resulted in increased inception of FDIs

4) Many FDI is in the manufacturing and Hospitality Industry

5) The FDI's in the hospitality industry are engaged in the importation of tourism facilities, manufacturing of hospitality items, engaged in the tour business, construction of hotels, etc.

All these combined have greatly influenced the growth of the tourism sector in Liberia. Therefore, the emergency of the bilateral relationship between Liberia and China has influenced the emergency of Chinese FDIs which has positively influenced the tourism sector in the past 10 years.

Despite occasional shocks such as the financial crisis of 2009, the global tourism industry has shown virtually uninterrupted growth. Tourism shows particular promise for developing countries. The tourism industry is one of the largest and fastest-growing sectors in the global economy and a key driver of socio-economic development, as it is labor-intensive and stimulates SME growth and investment (Dowen, 2016). Tourism has been used in other countries as an economic driver for growth which can widely support poverty reduction. Tourism also has an important spillover effect, spurring growth is closely related to sectors and subsectors such as agriculture, furniture manufacturing, foods and beverages, and infrastructure development (Panton, 2015). The more vibrant tourism industry in Liberia is achievable and will act as a means of enabling economic development while improving employment and overall socio-economic development. Liberia enjoys a rich natural capital with high touristic potential which can be leveraged in a reasonable time frame (Panton, 2015). There are significant challenges to overcome but the opportunities far outweigh the challenges. Other post-conflict destinations have been able to overcome their negative international image in the process of reviving their tourism industry. Their efforts required integrated approaches, public-private sector partnerships, investment, and marketing campaigns, among others (Panton, 2015). The future of Liberian tourism is bright, provided sector stakeholders, including Liberian policymakers and enterprises, can remain focused on this important endeavor.

\section{Acknowledgments}

The researchers extend heartfelt thanks and appreciation to the Department of tourism management for the numerous assistance. This work could not have been possible without assistance rendered by the groups aforementioned.

\section{Supplementary Materials}

All analyzed data are provided in full in the results section of this manuscript and detail references will be provided upon request.

\section{Funding}

The research project was funded by the Philosophy and Social Sciences Planning Project of Henan Province (Grant No. BJJ047). The funders had no role in study design, data collection, and analysis, decision to publish, or preparation of the manuscript.

\section{Conflicts of Interest}

The authors declare that they have no conflict of interest.

\section{References}

Abdillah, F., Janianton. D., Chafid, F., \& Sudarmadji. (2015). Development of Tourism Destination and Quality of Life of Local Communities. Mimbar Journal, 31(2), 339-350. https://doi.org/10.29313/mimbar.v31i2.1441

Cohen, E. H. (2008). Youth Tourism to Israel. Educational Experiences of the Diaspora. Clevedon: Channel View Publications. https://doi.org/10.21832/9781845410865

Cooper, R. D., \& Emory, C. W. (2006). Business Research Methods (5th ed.). Translated by Ellen Gunawan and Imam Nurmawan, Jakarta: Erlangga.

Davidson, A. C., \& Hinkley, D. V. (2006). Bootstrap Methods and Their Application. 
Dumasari, \& Tri, S. M. R. (2016). Management Strategy of Creative Souvenir Micro Enterprise for The Empowerment of Craftsmen Peasant. Mimbar Journal, 32(1), 175-186. https://doi.org/10.29313/mimbar.v32i1.1717

Dwyer, L. K. C. (2003). Destination Competitiveness: Determinants and Indicators. Current Issues in Tourism, 6(5), 369-414. https://doi.org/10.1080/13683500308667962

Erhamwilda, Asep, D. S., \& Nurul, A. (2017). Analysis of Early Childhood Teacher Perceptive of Sex Education from an Islamic Perspective. Mimbar Journal, 33(1), 8189. https://doi.org/10.29313/mimbar.v33i1.2071

Ferdinand, A. (2006). Research Methods Management: Research Guidelines for Essay. Thesis, and Dissertation in Management Science. Semarang: Universitas Diponegoro.

Ghazali, G. (2006). Structural Equation Modelling: Alternative Method with Partial Least Square. Semarang: Penerbit Universitas Diponegoro.

Ghozali, I. (2012). Application of Multivariate Analysis with SPSS Program. Semarang: Universitas Diponegoro.

Godfrey, K., \& Clarke, J. (2000). The tourism development handbook: A practical approach to planning and marketing. London: Continuum.

Kedaulatan Rakyat Daily Report. (2012, July 17). Reading Tourism Planning DIY 2025. Retrieve from http://hpijogja. wordpress.com/2012/07/17/membacaperencanaan-pariwisata-diy-2025/.

Malhotra, N. K., \& Birks, D. F. (2007). Marketing Research: An Applied Approach (3rd ed.). Harlow, UK: Pearson Education. https://doi.org/10.1108/S1548-6435(2007)3

Monecke, A., \& Leisch, F. (2012). SemPLS: Structural Equation Modeling Ysung Partial Least Squares. Journal of Statistical Software, 48(3), 1-32. https://doi.org/10.18637/jss.v048.i03

Rakhmat, J. (2001). Communication Psychology. Bandung: PT Remaja Rosdakarya.

Richards, G., \& Wilson, J. (2006). Developing Creativity in Tourist Experience: A Solution to the Social Reproduction of Culture. Tourism Management, 27(6), 1209-23. https://doi.org/10.1016/j.tourman.2005.06.002

Riduwan. (2009). Measurement Scale of Research Variables. Bandung: Alfabeta.

Ritchie, B.W. (2003). Managing Educational Tourism. Clevedon: Cromwell Press. https://doi.org/10.21832/9781873150528

Saepudin, Jajat, S. A., Ade, S. A., \& Ani, R. (2017). The Influence of Participation in Extracurricular Activities on Learning Motivation. Mimbar Journal, 33(2), 251-258. https://doi.org/10.29313/mimbar.v33i2.2223

Santoso, S. (2002). Processing Statistics Data in Professionally Way. Jakarta: PT. Alex Media Komputindo.

Sarwono, J. (2006). Quantitative and Qualitative Research Methods. Yogyakarta: Graha Ilmu.

Sharpley, R., \& Telfer, D. J. (2002). Tourism and Development Concept and Issues. Clevedon: Channel View Publications.

Smith, A. (2013). The Role of Educational Tourism in Raising Academic Standards. African Journal of Hospitality, Tourism and Leisure, 2(3), 1-7.

Swarbrooke, J. (2002). The Development and Management of Visitors Attractions. London: Routledge. https://doi.org/10.1016/B978-0-7506-5169-1.50046-7

Tanenhaus, M., Vinci, E. V., Yves, M. C., \& Carlo, L. (2005). PLS Path Modeling. Computational Statistic \& Data Analysis, 48, 159-205. https://doi.org/10.1016/j.csda.2004.03.005

Umar, H. (2003). Methods of Business Research. Jakarta: Gramedia Pustaka Utama.

Vengesayi, S. (2003). A Conceptual Model of Tourism Destination Competitiveness and Attractiveness. Anzmac 2003 Conference proceedings, Adelaide, Australia, 637-647. Retrieved from http://www.anzmac.org/conference_archive/2003/papers/CON20_vengesayis.pdf

Wang, B. (2008). Education Tourism Market in China An Explorative Study in Dalian. International Journal of Business and Management, 3(5), 44-49. https://doi.org/10.5539/ijbm.v3n5p44

Wijayanti, A., Janianton, D., Chafid, F., \& Sudarmadji. (2017). Analysis of Supply and Demand to Enhance Educational Tourism Experience in the Smart Park of Yogyakarta, Indonesia. Economics Journal, 5(4), 98-111. https://doi.org/10.3390/economies5040042 
Woodside, A., \& Martin, D. (2007). Tourism Management: Analysis, Behavior, and Strategy. Oxfordshire: CAB International.

Yoon, Y. (2002). Development of a Structural Model for Tourism Destination Competitiveness from Stakeholder' Perspective (Doctoral Dissertation). Virginia Polytechnic Institute and State University. Retrieved from https://theses.lib.vt.edu/theses/available/etd-10032002165524/unrestricted/TourismDestinationCompetitiven ess YooshikYoon.pdf

Yuan, Y. E., \& Wu, C. K. (2008). Relationship Among Experiential Marketing, Experiential Value, and Customer Satisfaction. Journal of Hospitality \& Tourism Research, 32(3), 387-410. https://doi.org/10.1177/1096348008317392

\section{Copyrights}

Copyright for this article is retained by the author(s), with first publication rights granted to the journal.

This is an open-access article distributed under the terms and conditions of the Creative Commons Attribution license (http://creativecommons.org/licenses/by/4.0/). 